\title{
Intraspecific variation in drought response of Populus cathayana grown under ambient and enhanced UV-B radiation
}

\author{
Yanwei LU $^{1,2, *}$, Baoli DUAN ${ }^{1, *}$, Xiaolu ZHANG ${ }^{1}$, Helena KorPELAINEN $^{3}$, Frank BERNINGER $^{4}$, \\ Chunyang $\mathrm{LI}^{1, * *}$ \\ ${ }^{1}$ Chengdu Institute of Biology, Chinese Academy of Sciences, P.O. Box 416, 610041 Chengdu, China \\ ${ }^{2}$ School of Life Sciences, Liaocheng University, 252059 Liaocheng, China \\ ${ }^{3}$ Department of Applied Biology, P.O. Box 27, 00014 University of Helsinki, Finland \\ ${ }^{4}$ Département des sciences biologiques, Cp 8888 succ centre ville, Université du Québec à Montréal, Montréal (QC) H3C 3P8, Canada
}

(Received 26 October 2008; revised version 22 February 2009; accepted 28 February 2009)

Keywords:

carbon nitrogen ratio /

photosynthetic nitrogen use efficiency /

Populus cathayana /

ultraviolet-b radiation /

water use efficiency
Mots-clés :

rapport carbone /

azote /

efficience photosynthétique

d'utilisation de l'azote /

Populus cathayana /

rayonnement UV-B /

efficience d'utilisation de l'eau

\footnotetext{
* Equal contribution to work.

**Corresponding author: licy@ cib.ac.cn
}

\begin{abstract}
- The effects of drought, enhanced UV-B radiation and their combination on plant growth and physiological traits were investigated in a greenhouse experiment in two populations of Populus cathayana Rehder originating from high and low altitude in south-west China.

- In both populations, drought significantly decreased biomass accumulation and gas exchange parameters, including net $\mathrm{CO}_{2}$ assimilation rate $(A)$, stomatal conductance $\left(g_{s}\right)$, transpiration rate $(E)$ and photosynthetic nitrogen use efficiency (PNUE). However, instantaneous water use efficiency $\left(W U E_{\mathrm{i}}\right)$, transpiration efficiency $\left(W U E_{\mathrm{T}}\right)$, carbon isotope composition $\left(\delta^{13} \mathrm{C}\right)$ and nitrogen $(\mathrm{N})$ content, as well as the accumulation of soluble protein, UV-absorbing compounds and abscisic acid (ABA) significantly increased in response to drought. On the other hand, cuttings from both populations, when kept under enhanced UV-B radiation, showed very similar changes, as under drought, in all above-mentioned parameters.

- Compared with the low altitude population, the high altitude population was more tolerant to drought and enhanced UV-B, as indicated by the higher level of biomass accumulation, gas exchange, water-use efficiency, ABA concentration and UV-absorbing compounds.

- After one growing season of exposure to different UV-B levels and watering regimes, the decrease in biomass accumulation and gas exchange, induced by drought, was more pronounced under the combination of UV-B and drought. Significant interactions between drought and UV-B were observed in $W U E_{\mathrm{i}}, W U E_{\mathrm{T}}, \delta^{13} \mathrm{C}$, soluble protein, UV-absorbing compounds, $\mathrm{ABA}$ and in the leaf and stem $\mathrm{N}$, as well as in the leaf and stem $\mathrm{C}: \mathrm{N}$ ratio.

- Our results showed that UV-B acts as an important signal allowing P. cathayana seedlings to respond to drought and that the combination of drought and UV-B may cause synergistically detrimental effects on plant growth.
\end{abstract}

Résumé - Variations intra-spécifiques de la réponse à la sécheresse de Populus cathayana sous atmosphère ambiante ou sous un rayonnement UV-B accru.

- Les effets d'une sécheresse, d'une augmentation du rayonnement UV-B et de leur combinaison ont été étudiés sur la croissance et les caractéristiques physiologiques de plants de deux populations de Populus cathayana Rehder originaires de haute et basse altitude dans le sud-ouest de la Chine.

- Dans les deux populations, la sécheresse a réduit de manière significative l'accumulation de biomasse et les échanges gazeux foliaires, y compris l'assimilation nette $(A)$ de $\mathrm{CO}_{2}$, la conductance stomatique $\left(g_{s}\right)$, la transpiration $(E)$ et l'efficience photosynthétique d'utilisation de l'azote (PNUE). Toutefois, l'efficience instantanée d'utilisation de l'eau $\left(W U E_{\mathrm{i}}\right)$, l'efficience de transpiration $\left(W U E_{\mathrm{T}}\right)$, la composition isotopique du carbone $\left(\delta^{13} \mathrm{C}\right)$ et le contenu en azote $(\mathrm{N})$, ainsi que l'accumulation de protéines solubles, des composés absorbant les UV et de l'acide abscissique (ABA) 
ont présenté une augmentation significative en réponse à la sécheresse. D'autre part, des boutures des deux populations, quand elles ont été conservées sous un rayonnement UV-B renforcé, ont montré des changements de tous les paramètres mentionnés ci-dessus, similaires à ceux induits par la sécheresse. - Par rapport à la population de faible altitude, la population de haute altitude, était plus tolérante à la sécheresse et au renforcement du rayonnement UV-B; cela s'est traduit par le niveau plus élevé d'accumulation de biomasse, d'échanges gazeux, de l'efficience d'utilisation de l'eau, de la concentration d'ABA et des composés absorbant les UV.

- Après une saison de croissance, la diminution de l'accumulation de biomasse et des échanges gazeux induite par la sécheresse, était plus prononcée dans le cadre de la combinaison du rayonnement UV-B et de la sécheresse. Des interactions significatives entre sécheresse et UV-B ont été observées pour $W U E_{\mathrm{i}}, W U E_{\mathrm{T}}, \delta^{13} \mathrm{C}$, les protéines solubles, les composés absorbant les UV, l'ABA et l'azote des feuilles et des tiges, ainsi que pour le rapport $\mathrm{C} / \mathrm{N}$ des feuilles et des tiges.

- Nos résultats ont montré que les UV-B agissent comme un signal important en permettant aux jeunes plants de $P$. cathayana de faire face à la sécheresse et que la combinaison de la sécheresse et des UV-B peut causer par synergie des effets néfastes pour la croissance des plants.

\section{INTRODUCTION}

In a natural environment, plants are typically exposed to several stress factors simultaneously. Alexieva et al. (2001) have shown that UV-B stress exceeds the effects of drought stress on the superoxide dismutase (SOD) and catalase (CAT) activities in pea (Pisum sativum L., cv. Citrina) and wheat (Triticum aestivum L., cv. Centauro). However, UV-B radiation has been reported to alleviate drought stress of plants due to changes in epidermal anatomy (Petropoulou et al., 1995) and increases in carbon assimilation (Sullivan and Teramura, 1989). Meanwhile, interactive responses of Quercus suber L. seedlings to light and moderate water stress have been reported by Puértolas et al. (2008). Studies on the combined effects of UV-B radiation and drought stress on trees have been conducted in some species, e.g., Mediterranean pines (Pinus pinea L.) (Petropoulou et al., 1995), olive (Olea europaea L.) (Noguès and Baker, 2000), Douglas fir (Pseudotsuga menziesii Franco) (Poulson et al., 2002) and willows (Salix myrsinifolia L.) (Turtola et al., 2006), and it appears that species differ in their responses to multiple stress factors. The interaction between UV-B radiation and moderate drought is still not well-understood. Furthermore, evidence from plant research indicates that there can be altitudinal variation in response to UV-B (Hubner and Ziegler, 1998; Rau and Hofmann, 1996). However, few studies have examined the same species from both high and low altitude sites (Yang et al., 2005). Such limited numbers of studies do not allow us to establish any general conclusion, whether high altitude populations differ from low elevation populations in response to UV-B.

Water use efficiency (WUE) is traditionally defined either as the ratio of dry matter accumulation to water consumption over a season $\left(W U E_{\mathrm{T}}\right)$ or as the ratio of photosynthesis $(A)$ to transpiration $(E)$ over a period of seconds or minutes $\left(W U E_{\mathrm{i}}\right)$ (Sinclair et al., 1984). More recently, carbon isotope composition $\left(\delta^{13} \mathrm{C}\right)$ has been developed as a tool to measure WUE, because a strong correlation has been found between $\delta^{13} \mathrm{C}$ and WUE (Farquhar et al., 1989). $\delta^{13} \mathrm{C}$ of plant tissue provides an integrated measurement of internal plant physiological and external environmental properties influencing photosynthetic gas exchange over time, when the carbon content is fixed (Li, 2000). On the other hand, carbon, nitrogen, phosphorus and sulphur are of central interest among macronutrients. The functions of these elements in structure, and in primary and energy metabolism are strongly connected in a network of reactions and structures (Grossman and Takahashi, 2001). Previous studies have revealed that changes in nutrient concentrations, as a response to increased UV-B radiation, are primarily attributable to changes in dry matter production and allocation (Weih et al., 1998). However, the effects of UV-B radiation on $W U E$ and the contents of mineral nutrients have been studied relatively little in woody plants, in particular, as affected by the combination of enhanced UV-B radiation and drought.

Previously, several field and greenhouse experiments have been conducted to determine the effect of UV-B radiation on the growth and physiological responses of poplars (Bassman et al., 2003; Ren et al., 2007; Schumaker et al., 1997). However, the mechanisms of sensitivity or tolerance of tree species, either in growth or physiology, to combined stresses remain unknown. According to Piper et al. (2007), differences in tolerance detected in the two evergreen trees Nothofagus nitida (Phil.) Krasser and N. dombeyi (Mirb.) Blume are associated with differences in geographic distribution. In this study, we examined two Populus cathayana Rehder populations that originated from high and low altitudes in southwest China. The contribution of UV-B radiation to total solar radiation tends to increase with altitude, and high altitude populations typically grow under more intensive physiological drought induced by frozen or unavailable soil water, or damaged foliage. It may be possible that the high altitude population possesses more potential to acclimatize to environmental changes than does the low altitude population. We tested the hypothesis that the high altitude population exposed to stress present also in its natural habitat would be less affected by enhanced UV-B radiation and drought than is the population originating from low altitude. Moreover, we hypothesized that an interaction between drought and UV-B radiation would be present, since drought periods coincide with sunny conditions and high exposure to UV-B radiation. More specifically, we aimed (1) to determine whether growth and physiological traits of $P$. cathayana are affected by exposure to enhanced UV-B radiation, drought and their combination, and 
(2) to evaluate population differences in responses to enhanced UV-B radiation, drought and their combination.

\section{MATERIALS AND METHODS}

\subsection{Plant materials and experimental design}

A high altitude population (Datong, $36^{\circ} 15^{\prime} \mathrm{N}, 101^{\circ} 40^{\prime} \mathrm{E}$ ) and a low altitude population (Jiuzhai, $32^{\circ} 33^{\prime} \mathrm{N}, 101^{\circ} 27^{\prime} \mathrm{E}$ ) of P. cathayana from contrasting habitats were selected for our study. The mean altitude equals $2840 \mathrm{~m}$ and $1450 \mathrm{~m}$, the average daily biologically effective radiation (UV-B $\mathrm{BE}_{\mathrm{BE}}$ ) is $6.5 \mathrm{~kJ} \mathrm{~m}^{-2}$ day $^{-1}$ and $4.7 \mathrm{~kJ} \mathrm{~m}^{-2}$ day $^{-1}$ according to a mathematical model by Madronich et al. (1995) and $\mathrm{Li}$ et al. (2002), and the mean annual rainfall is $620 \mathrm{~mm}$ and $553 \mathrm{~mm}$ at the origin of the high and low altitude population, respectively. The cuttings were collected from 20 ortets of the same age stage from each population and planted in March, 2006. After sprouting and growing for about 1 month, healthy cuttings of uniform height collected from each population were transplanted into 10-L plastic pots filled with homogenized brown soil and grown in a greenhouse under a semi-controlled environment with a day temperature range of $12-31{ }^{\circ} \mathrm{C}$, a night temperature range of $9-15{ }^{\circ} \mathrm{C}$ and a relative humidity range of $35-85 \%$ at the Maoxian field ecological station of the chinese academy of sciences. The 10-L pots used in the study had a soil volume large enough to alleviate rapid temperature transitions and high absolute temperatures. To avoid the effects of rainfall, a $0.08 \mathrm{~mm}$ thick polyethylene film (Chengguang Chem. Inc., Sichuan, China), which could transmit $80 \%$ of the ambient solar UV-B radiation ( $280-320 \mathrm{~nm}$ ) and $85 \%$ of the visible radiation (400$700 \mathrm{~nm}$ ), was employed as a cover. The experiment was conducted during the growing season from June 1 to September 30, 2006.

Eighty cuttings of each population were subjected to four treatments as follows: (a) well-watered+no enhanced UV-B radiation, (b) well-watered+enhanced UV-B radiation, (c) drought+no enhanced UV-B radiation and (d) drought+enhanced UV-B radiation. In each treatment, there were 20 cuttings from each population, arranged into five blocks. Evaporation from the soil surface was prevented by enclosing the pots in plastic bags that were tied to the stems of the plants. In the well-watered treatment, the pots were weighed every other day and re-watered to $100 \%$ of field capacity (the volumetric soil water content was always kept at $24 \%$ ) by replacing the amount of water transpired. In the drought-stressed treatment, the pots were watered to $50 \%$ of field capacity (the volumetric soil water content was always kept at $13 \%$ ) by supplying an amount of water equal to evaporation losses every other day. Thus, the water content was kept constant throughout the whole experiment. In both well-watered and drought-stressed treatments, half of the cuttings were exposed to enhanced UV-B radiation, as described below, while another half of the cuttings were exposed to $80 \%$ ambient UV-B radiation as a control. A total of $4 \mathrm{~g}$ slow release fertilizer $(13 \% \mathrm{~N}, 10 \% \mathrm{P}$ and $14 \% \mathrm{~K})$ was added to each pot during the experiment. Measurements of various physiological traits were conducted within a 2 -week period in September.

\subsection{Ultraviolet-B radiation treatments}

The average daily biologically effective UV-B on the experimental site (Maoxian ecological station (103 $53^{\prime} \mathrm{E}, 31^{\circ} 41^{\prime} \mathrm{N}, 1816 \mathrm{~m}$,
China)), based on spectroradiometric measurements, equaled $5.5 \mathrm{~kJ} \mathrm{~m}^{-2} \mathrm{day}^{-1}$. In this experiment, square-wave UV-B supplementation systems were used. Supplemental UV-B radiation was applied over an 8-h (from 9:00 to 17:00) period centered at solar noon using UV fluorescent lamps (Beijing electronic resource Inc., Beijing, China) mounted in metal frames suspended above the pots. The distance between the lamps and the top of the plants was always regulated to obtain a similar UV-B dose for each exposed plant throughout the growing season. There were two UV-B radiation levels: with and without UV-B supplementation. In the treatment without UV-B supplementation, the plants received $80 \%$ of ambient UV-B radiation, and in the treatment with UV-B supplementation, the plants received $80 \%$ of ambient UV-B radiation plus supplemental levels of UV-B radiation. The plants without UV-B supplementation treatment were kept under lamps covered with polyester films, which absorb radiation below $315 \mathrm{~nm}$, to exclude both UV-B and UV-C radiation. For the UV-B supplementation treatments, the lamps were wrapped with cellulose diacetate film, which allowed the transmission of both UV-B and UV-A radiation. The cellulose diacetate films were changed weekly. The spectral irradiance from the lamps at plant level was determined by USB2000 Fibre Optic spectrometer (wavelength steps of $0.36 \mathrm{~nm}$ in the UV and visible range, ocean optics Inc., Dunedin, FL) with CC-3-UV Cosine Corrector. Before measurements, the spectrometer was calibrated with DH2000-CAL radiometric calibrated deuterium tungsten source (210-1 $050 \mathrm{~nm}$ national institute of standards and technology -traceable calibration, ocean optics Inc.). The spectral irradiance was weighed according to the generalized plant action spectrum (Caldwell, 1971) and normalized at $300 \mathrm{~nm}$ to obtain UV-B $B_{\mathrm{BE}}$. The daily UV-B supplementation was $8.0 \mathrm{~kJ} \mathrm{~m}^{-2} \mathrm{~d}^{-1}$ (UV-B $B_{B E}$ ). The spectral irradiance was equivalent to $4.4 \mathrm{~kJ} \mathrm{~m}^{-2} \mathrm{~d}^{-1}$ and $12.4 \mathrm{~kJ} \mathrm{~m}^{-2} \mathrm{~d}^{-1}$ biologically effective UV-B radiation (UV-B $\mathrm{B}_{\mathrm{BE}}$ ) under polyester films and cellulose diacetate, respectively. In each population, four cuttings from each block received UV-B treatment from a single lamp. These cuttings were rotated weekly in order to minimize the effects of the microenvironment.

\subsection{Growth measurements and relative water content}

Ten cuttings were harvested at the end of the experiment and divided into leaves, stems and roots. Biomass samples were dried $\left(70{ }^{\circ} \mathrm{C}, 48 \mathrm{~h}\right.$ ) to constant weight and weighed. The root/shoot ratio $(R / S)$ and the relative water content $(R W C, \%)$ of leaves were then calculated. The leaf disks $\left(5.02 \mathrm{~cm}^{2}\right)$ were cut at $8: 00 \mathrm{~h}$ in the morning and immediately taken to the laboratory for weighing. The samples were first hydrated to full turgidity by immersing them in deionized water in a closed Petri dish for $24 \mathrm{~h}$, then removed from the water, dried on the surface using filter paper, and weighed to get the turgid weight. The samples were then oven-dried at $80^{\circ} \mathrm{C}$ for $24 \mathrm{~h}$ to constant weight and weighed. The relative water content of leaves was then calculated using the equation: $R W C(\%)=$ $(W f-W d) /(W t-W d) \times 100 \%$, where $W f$, the fresh weight; $W d$, the dry weight; $W t$, the turgid weight.

\subsection{Gas exchange}

The photosynthetic gas exchange measurement was conducted for the second fully expanded leaf from five seedlings in each treatment using portable photosynthesis systems (model LI-6400, LI-COR Inc., Lincoln NE) between 8:00 and 11:00 in September. 
Each measuring day, the infrared gas analyzers (IRGAs) of LI-6400 were first calibrated following the manufacturer's instructions. When measuring leaf net photosynthetic rates $(A)$, stomatal conductance $\left(g_{s}\right)$ and transpiration rate $(E)$, the system maintained a constant $1700 \mu \mathrm{mol} \mathrm{m}{ }^{-2} \mathrm{~s}^{-1} \mathrm{PAR}, 25{ }^{\circ} \mathrm{C}$ leaf temperature, and $50 \%$ R.H. The ratio of $A$ to $E$ was taken as the instantaneous $W U E$ (WUE $E_{\mathrm{i}}$, and the ratio of $A$ to $\mathrm{N}$ content in the leaves was regarded as the photosynthetic nitrogen use efficiency (PNUE).

\subsection{Transpiration efficiency}

Transpiration efficiency $\left(W U E_{\mathrm{T}}\right)$ was determined for five cuttings by dividing the total dry matter production by the cumulative amount of water used throughout the growing season. The total dry matter included oven-dried leaves, stems and roots. Dry matter at transplanting was estimated from allometric relationships, the diameter and height of the cuttings from each population, and subtracted from the final dry matter to estimate the total dry matter production over the course of the experiment.

\subsection{Carbon isotope composition}

Leaf samples of five seedlings used for the carbon isotope analysis were oven-dried for $24 \mathrm{~h}$ at $80{ }^{\circ} \mathrm{C}$ and homogenized. The carbon isotope composition $\left(\delta^{13} \mathrm{C}\right)$ of combusted samples was measured with a mass spectrometer (Finnegan MAT Delta-E), as described by Li et al. (2000). $\delta^{13} \mathrm{C}$ was expressed relative to the PeeDee Belemnite standard (Craig, 1957). The overall precision of the $\delta$-values was better than $0.1 \%$, as determined from repeated samples.

\subsection{Soluble protein content determination}

The amount of soluble proteins was quantified using the method of Bradford (1976). Leaves (0.2 g) were homogeneized in a grinding medium that contained $50 \mathrm{mM}$ phosphate buffer $(\mathrm{pH} 7.8), 0.1 \mathrm{mM}$ EDTA, $100 \mu \mathrm{M}$ PMSF and 2\% PVP (w/v). Bovine serum albumin was used as a standard.

\subsection{Quantitative analysis of abscisic acid $(A B A)$}

For each population and treatment, ABA present in the apical buds of five seedlings from five blocks (one seedling from each block) was randomly analyzed as described by Li et al. (2002). The samples were weighed, frozen in liquid nitrogen and freeze-dried. Then, $30-50 \mathrm{mg}$ of leaf sample was homogenized in $5 \mathrm{~mL}$ of $50 \mathrm{mM}$ sodium phosphate buffer, $\mathrm{pH} 7.0$, with $0.02 \%$ sodium diethyldithiocarbamate as antioxidant and $30 \mathrm{ng}{ }^{2} \mathrm{H}_{4} \mathrm{ABA}$ as internal standard, and the samples were analyzed as described by $\mathrm{Li}$ et al. (2002). Ions at 190.1 and 194.1 were monitored, and the amount of ABA in the sample was calculated using a standard curve drawn from the area ratios of known amounts of ABA and ${ }^{2} \mathrm{H}_{4}$ ABA. The endogenous ABA level was calculated in $\mu \mathrm{g} \mathrm{g}^{-1} \mathrm{FW}$.

\subsection{Measurement of UV-B absorbing compounds}

UV-B absorbing compounds were extracted from fresh leaf material of five seedlings with an acidified methanol solution (methanol: water: $\mathrm{HCl}=79: 20: 1$ ) (Dai et al., 2004). The absorbance of the solution was measured at $300 \mathrm{~nm}$ using spectrophotometry (Unicam UV-330, USA). The concentration of the UV-absorbing compounds was calculated on the basis of fresh weight.

\subsection{Determination of carbon and nitrogen contents}

The samples of leaves, stems and roots were ground and passed through a 20 mesh screen after being dried at $80{ }^{\circ} \mathrm{C}$ for $36 \mathrm{~h}$. The total contents of nitrogen $(\mathrm{N})$ and organic carbon $(\mathrm{C})$ were determined by the semi-micro Kjeldahl method and the rapid dichromate oxidation technique (Nelson and Sommers, 1982), respectively. The total C to $\mathrm{N}$ ratio $(\mathrm{C}: \mathrm{N})\left(\mathrm{g} \mathrm{g}^{-1} \mathrm{DW}\right)$ was calculated as an estimate for the longterm nitrogen use efficiency (Livingston et al., 1999).

\subsection{Statistical analyses}

All measurements were tested by a three-way ANOVA for the effects of UV-B, drought and population. Before ANOVA, data were checked for normality and the homogeneity of variances, and log-transformed to correct deviations from these assumptions when needed. The analyses were performed with the general linear ANOVA model (GLM) procedure of SPSS 11.0 (SPSS Inc., Chicago, IL). Post-hoc comparisons were tested using the Duncan's test at a significance level of $P<0.05$.

\section{RESULTS}

\subsection{Drought and UV-B radiation effects on biomass accumulation and $R W C$}

In both populations, biomass accumulation showed a significant decrease in response to drought and UV-B radiation alone, while an even more pronounced decrease occurred when the two stresses were applied together (Tab. I). The ratio $R / S$ was unaffected by drought in both populations, by enhanced UV-B radiation in the low altitude population and by the combination of both factors in the low altitude population. $R W C$ was not affected by enhanced UV-B radiation alone in either population, while it significantly decreased under drought in both populations (Tab. I). Significant population differences were found in all parameters. Generally, the high altitude population had a higher biomass accumulation, $R / S$ and $R W C$ in comparison with the low altitude population (Tab. I). In addition, a significant interaction between drought and UV-B radiation was detected in all biomass parameters except in $R W C$. 
Table I. Biomass accumulation measurements in two contrasting $P$. cathayana populations exposed to different UV-B levels under well-watered or drought-stressed conditions.

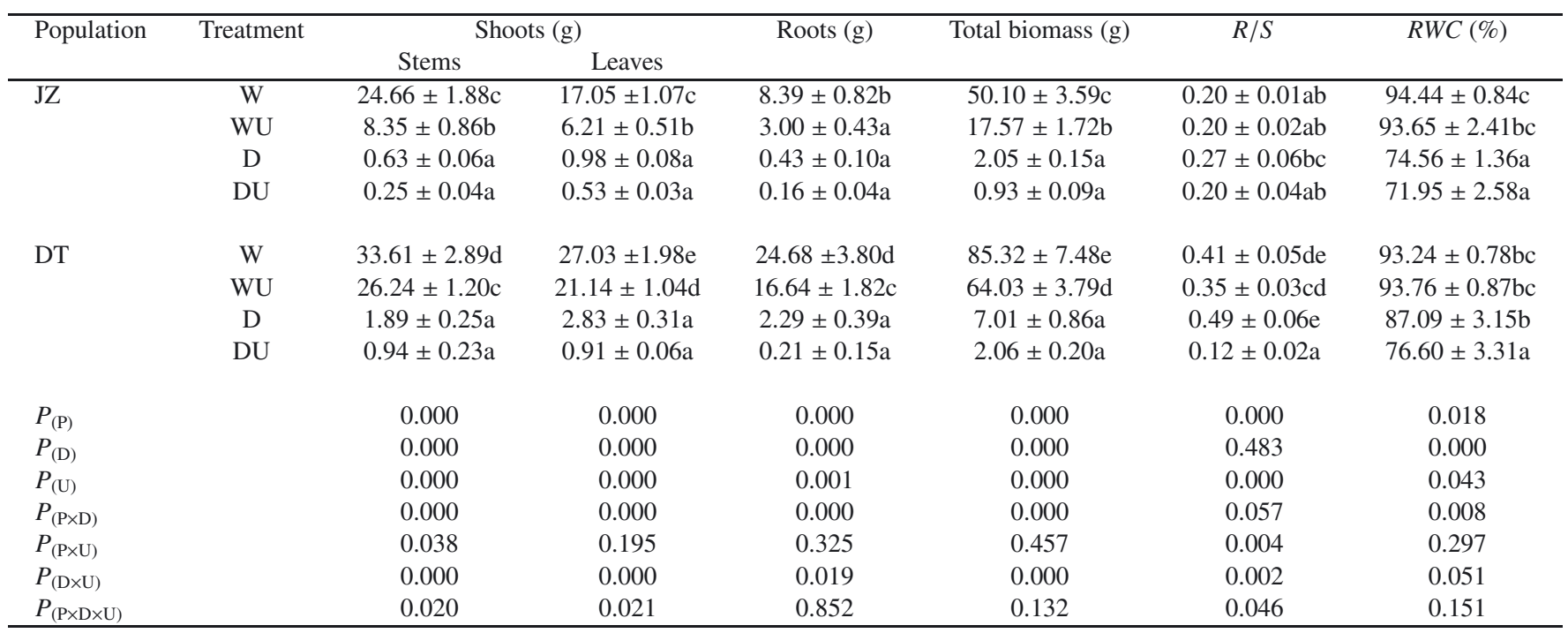

JZ, the low altitude population; DT, the high altitude population. ANOVA: $P_{(\mathrm{P})}$ : population effect; $P_{(\mathrm{D})}$ : drought effect; $P_{(\mathrm{U})}:$ UV-B effect; $P_{(\mathrm{P} \times \mathrm{D})}$ : population $\times$ drought effect; $P_{(\mathrm{P} \times \mathrm{U})}$ : population $\times \mathrm{UV}-\mathrm{B}$ effect; $P_{(\mathrm{D} \times \mathrm{U})}$ : drought $\times \mathrm{UV}-\mathrm{B}$ effect; $P_{(\mathrm{P} \times \mathrm{D} \times \mathrm{U})}$ : population $\times$ drought $\times \mathrm{UV}-\mathrm{B}$ effect. W, wellwatered; WU, well-watered+enhanced UV-B radiation condition; D, drought; DU, drought+enhanced UV-B radiation condition. Values followed by the same letter in the same column are not significantly different at the $P<0.05$ level according to Duncan's multiple range test. Values are means \pm $\mathrm{SE}, n=10$.

\subsection{Drought and UV-B radiation effects on $A, g_{s}$, $E$ and $P N U E$}

$A, g_{s}, E$ and PNUE all significantly decreased when the cuttings were exposed to enhanced UV-B radiation or drought (Tab. II). Compared with the low altitude population, the high altitude population had higher $A, g_{s}, E$ and PNUE values. The drought $\times$ UV-B radiation interaction effect was found in all these parameters (Tab. II).

\subsection{Drought and UV-B radiation effects on $W U E_{\mathrm{i}}$, $W U E_{\mathrm{T}}$ and $\delta^{13} \mathrm{C}$}

$W U E_{\mathrm{i}}, W U E_{\mathrm{T}}$ and $\delta^{13} \mathrm{C}$ were all significantly changed by drought, UV-B radiation and their combination (Fig. 1). The high altitude population had greater $W U E_{\mathrm{i}}$, and $W U E_{\mathrm{T}}$ values than did the low altitude population. Significant drought $\times$ UV-B radiation interaction effects were detected in all three variables (Tab. III).

\subsection{Drought and UV-B radiation effects on soluble protein, ABA and UV-absorbing compounds}

The concentration of ABA and UV-absorbing compounds increased significantly under a single stress caused by drought and enhanced UV-B radiation, while the amount of soluble protein significantly increased only under drought without any effect by UV-B radiation (Fig. 2). When drought and UV-B radiation were supplied together, ABA accumulated much more in the high altitude population. Population had significant effects on ABA and UV-absorbing compounds but not on soluble protein. Compared with the low altitude population, the high altitude population showed a higher level of ABA and UV-absorbing compounds. The interaction effect of drought $\times \mathrm{UV}-\mathrm{B}$ radiation was significant on all parameters (Tab. III).

\subsection{Drought and UV-B radiation effects on $\mathrm{C}, \mathrm{N}$ contents and $\mathrm{C}: \mathrm{N}$ ratio in leaves, stems and roots}

In the high altitude population, the leaf $\mathrm{C}$ content significantly decreased under drought and UV-B radiation, while the stem and root $\mathrm{C}$ contents were less affected by drought and UV-B radiation (Fig. 3). In the low altitude population, there were significant decreases in the leaf and stem $\mathrm{C}$ contents under drought, and in the stem and root $\mathrm{C}$ content under UV-B radiation. Significant population differences were detected in the stem and root $\mathrm{C}$ contents. No significant drought $\times \mathrm{UV}-\mathrm{B}$ radiation interaction was found in any of the three organs (Tab. III).

In relation to the $\mathrm{N}$ content, significant increases were detected in all organs in both populations, as induced by drought alone, except for leaves in the low altitude population (Fig. 4). Under enhanced UV-B radiation, significant increases of $\mathrm{N}$ were detected in other organs, except for leaves in the low altitude population and roots in both populations. In addition, the drought $\times \mathrm{UV}-\mathrm{B}$ radiation interaction significantly affected 
Table II. Gas exchange measurements in two contrasting $P$. cathayana populations exposed to different UV-B levels under well-watered or drought-stressed conditions.

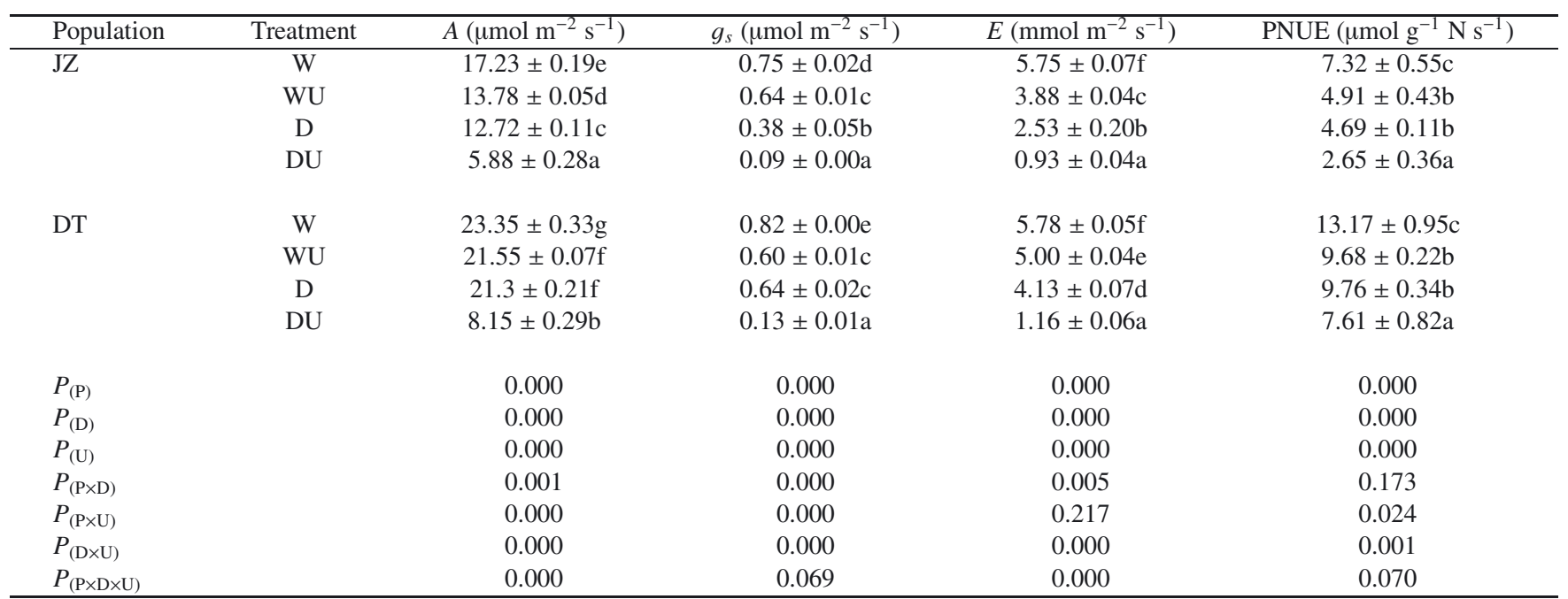

$\mathrm{JZ}$, the low altitude population; DT, the high altitude population. ANOVA: $P_{(\mathrm{P})}$ : population effect; $P_{(\mathrm{D})}$ : drought effect; $P_{(\mathrm{U})}: \mathrm{UV}-\mathrm{B}$ effect; $P_{(\mathrm{P} \times \mathrm{D})}$ : population $\times$ drought effect; $P_{(\mathrm{P} \times \mathrm{U})}$ : population $\times \mathrm{UV}-\mathrm{B}$ effect; $P_{(\mathrm{D} \times \mathrm{U})}$ : drought $\times \mathrm{UV}-\mathrm{B}$ effect; $P_{(\mathrm{P} \times \mathrm{D} \times \mathrm{U})}$ : population $\times$ drought $\times \mathrm{UV}-\mathrm{B}$ effect. W, wellwatered; WU, well-watered+enhanced UV-B radiation condition; D, drought; DU, drought+enhanced UV-B radiation condition. Values followed by the same letter in the same column are not significantly different at the $P<0.05$ level according to Duncan's multiple range test. Values are means \pm SE, $n=5$.

Table III. Statistical significance of the $P$ values (ANOVA) for the single and interactive effects of population, drought and enhanced UV-B radiation on different physiological parameters.

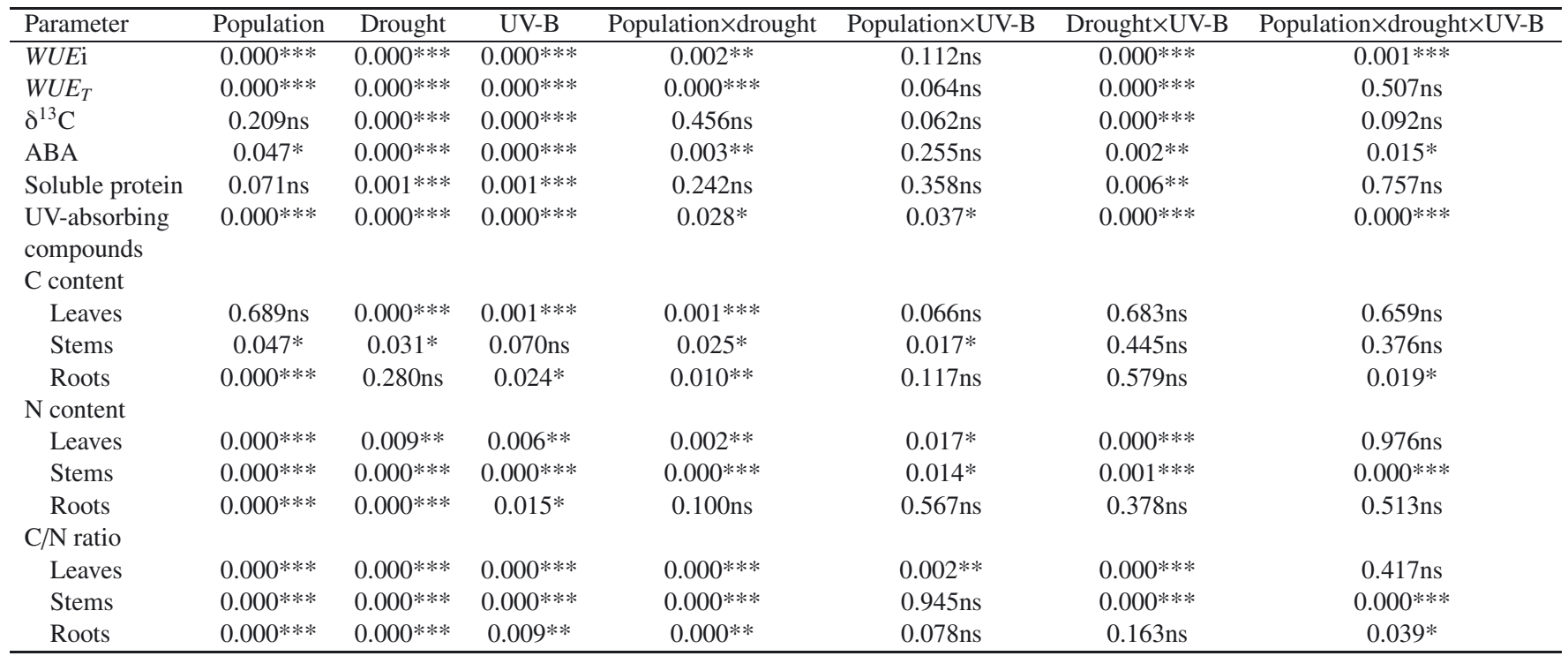

ns, not significant; *, $P<0.05$; **, $P<0.01$; ***, $P<0.001$.

$W U E_{i}=$ intrinsic water use efficiency; $W U E_{T}=$ transpiration efficiency; $\delta^{13} \mathrm{C}=$ stable isotope composition.

the $\mathrm{N}$ contents of leaves and stems. Compared with leaves, the $\mathrm{N}$ contents were lower in stems and roots in the low altitude population under all treatments. Also, there were significant population differences in the $\mathrm{N}$ contents of all organs (Tab. III).

The C:N ratios of stems significantly decreased under a single stress by drought or enhanced UV-B radiation in both populations, as also the $\mathrm{C}: \mathrm{N}$ ratio of leaves in the high alti- tude population, and the $\mathrm{C}: \mathrm{N}$ ratio of roots in the low altitude population (Fig. 5). In addition, drought affected the $\mathrm{C}: \mathrm{N}$ ratio of roots in the high altitude population. When exposed to the combination of these two stresses, most pronounced decreases were found in the leaf and stem $\mathrm{C}: \mathrm{N}$ ratio in the high altitude population. Population had a significant effect on the $\mathrm{C}: \mathrm{N}$ ratio of all organs (Tab. III). 

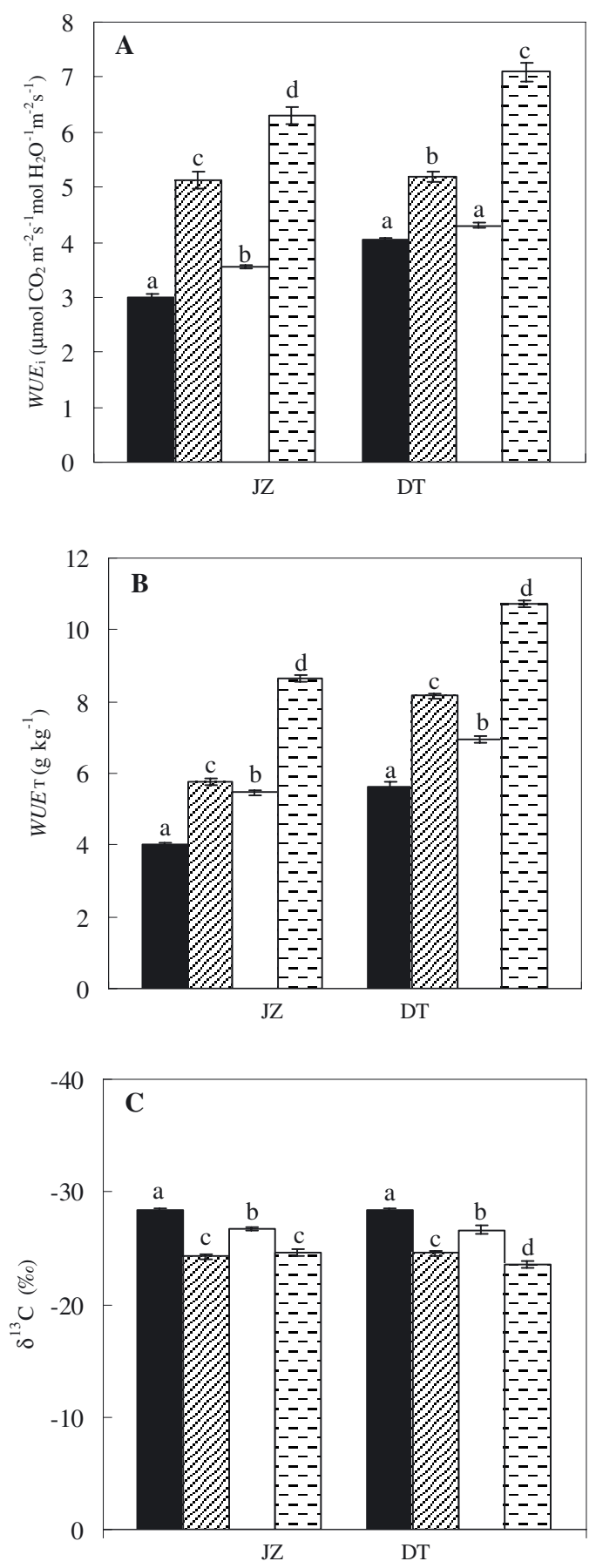

Figure 1. Instantaneous water use efficiency $\left(W U E_{\mathrm{i}}\right)(\mathrm{A})$, transpiration efficiency $\left(W U E_{\mathrm{T}}\right)(\mathrm{B})$ and carbon isotope composition $\left(\delta^{13} \mathrm{C}\right)$ (C) in two contrasting $P$. cathayana populations exposed to different UV-B levels under well-watered or drought-stressed conditions. JZ, the population from the low altitude; DT, the population from the high altitude. Treatments: well-watered+no enhanced UVB application (black area), drought+no enhanced UV-B application (lined area), well-watered+enhanced UV-B application (white area), drought+enhanced UV-B application (stippled area). Different letters above the bars denote statistically significant differences between treatments at the $P<0.05$ level according to Duncan's multiple range test. Values are means \pm SE, $n=5$.
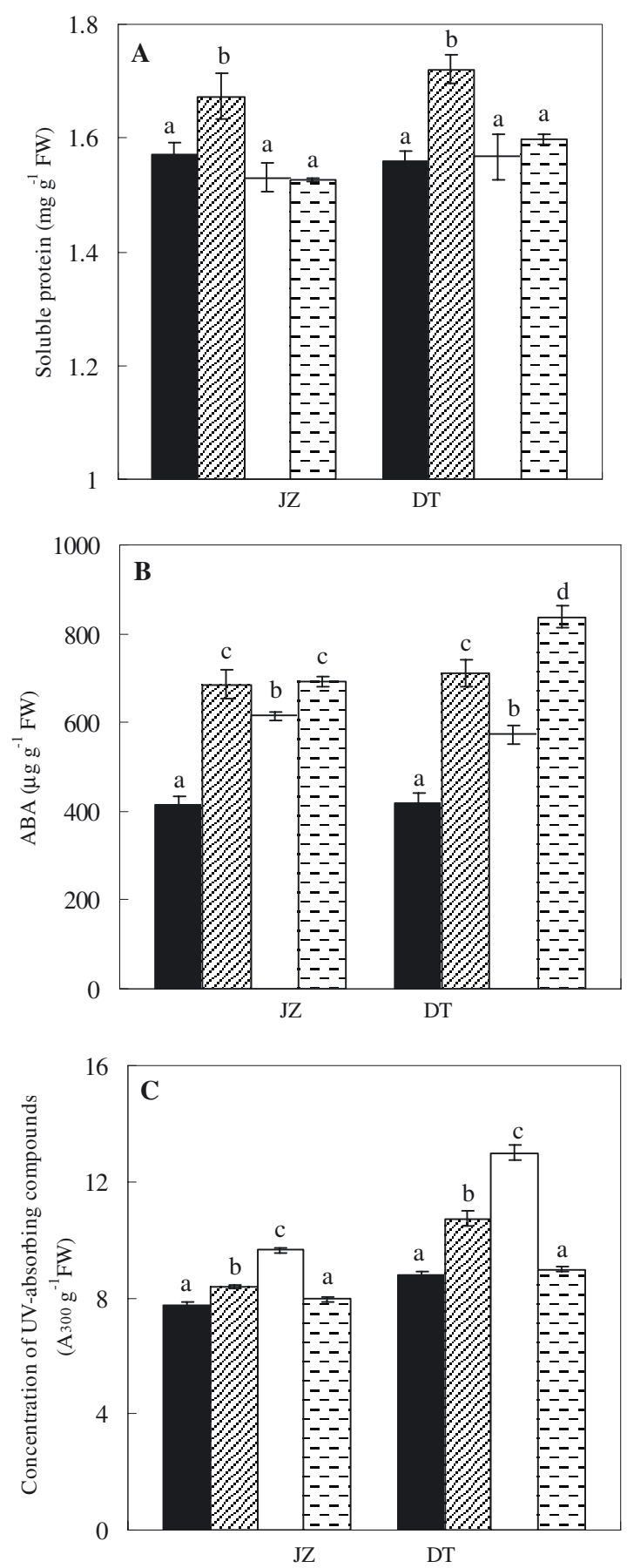

Figure 2. Soluble protein content (A), abscisic acid (ABA) concentration (B) and UV-absorbing compounds concentration (C) in two contrasting $P$. cathayana populations exposed to different UV-B levels under well-watered or drought-stressed conditions. FW: fresh weight. JZ, the population from the low altitude; DT, the population from the high altitude. Treatments: well-watered+no enhanced UVB application (black area), drought + no enhanced UV-B application (lined area), well-watered+enhanced UV-B application (white area), drought+enhanced UV-B application (stippled area). Different letters above the bars denote statistically significant differences between treatments at the $P<0.05$ level according to Duncan's multiple range test. Values are means $\pm \mathrm{SE}, n=5$. 

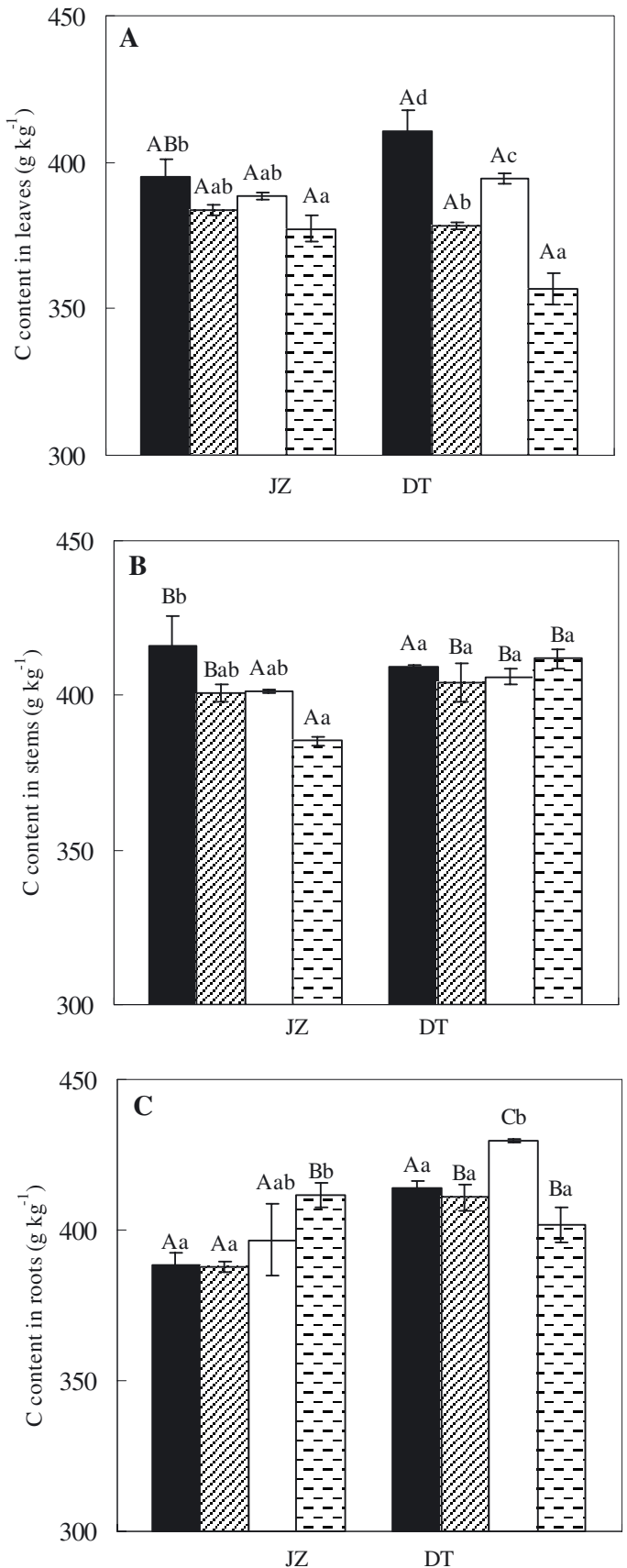

Figure 3. Carbon content in leaves (A), stems (B) and roots (C), respectively, in two contrasting $P$. cathayana populations exposed to different UV-B levels under well-watered or drought-stressed conditions. JZ, the population from the low altitude; DT, the population from the high altitude. Treatments: well-watered+no enhanced UVB application (black area), drought+no enhanced UV-B application (lined area), well-watered+enhanced UV-B application (white area), drought+enhanced UV-B application (stippled area). Values followed by the same small letters above the bars are not significantly different at $P<0.05$ level according to Duncan's multiple range test. Different capital letters above the bars refer to significant differences between the organs under the same population and treatment at the $P<0.05$ level according to Duncan multiple range test, respectively. Values are means $\pm \mathrm{SE}, n=5$.
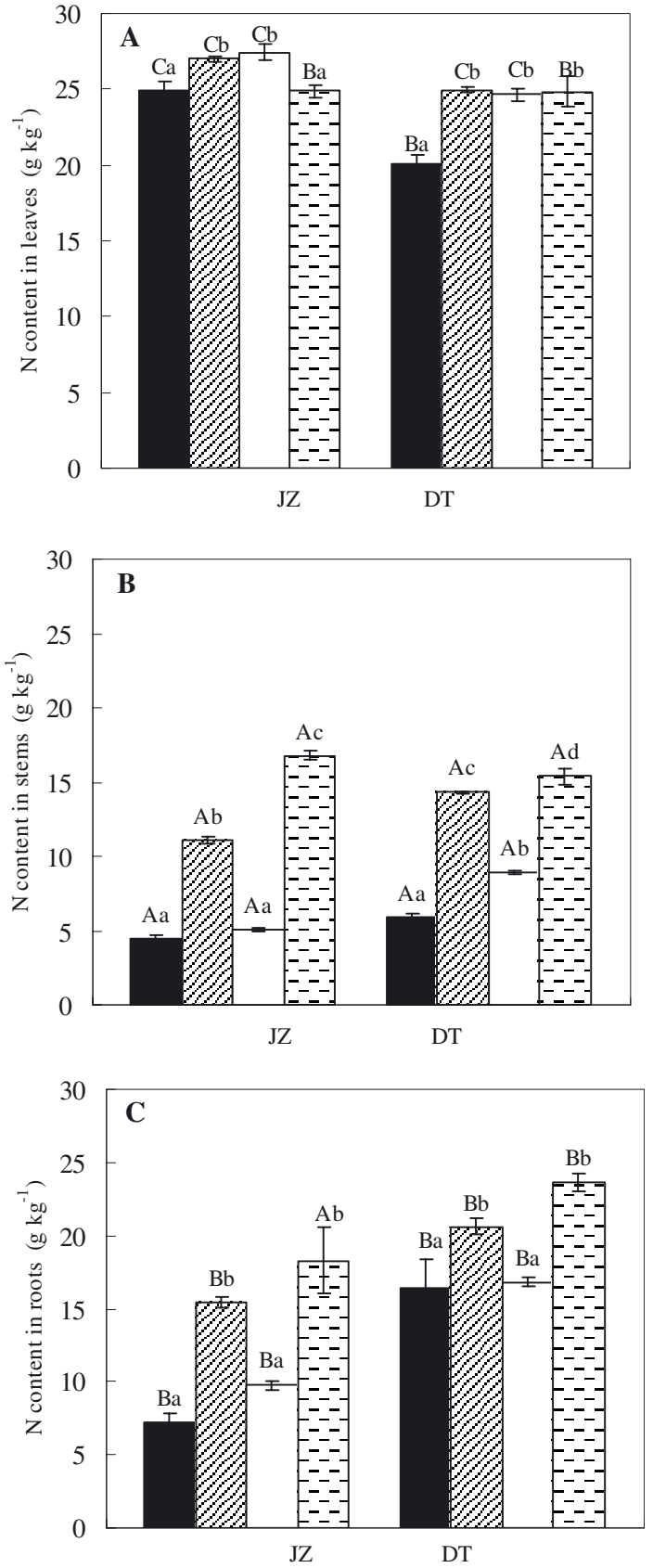

Figure 4. Nitrogen content in leaves (A), stems (B) and roots (C) based on dry weight in two contrasting $P$. cathayana populations exposed to different UV-B levels under well-watered or droughtstressed conditions. JZ, the population from the low altitude; DT, the population from the high altitude. Treatments: well-watered+no enhanced UV-B application (black area), drought+no enhanced UV-B application (lined area), well-watered+enhanced UV-B application (white area), drought+enhanced UV-B application (stippled area). Values followed by the same small letters above the bars are not significantly different at the $P<0.05$ level according to Duncan multiple range test. Different capital letters above the bars refer to significant differences between the organs under the same population and treatment at $P<0.05$ level according to Duncan's multiple range test, respectively. Values are means $\pm \mathrm{SE}, n=5$. 

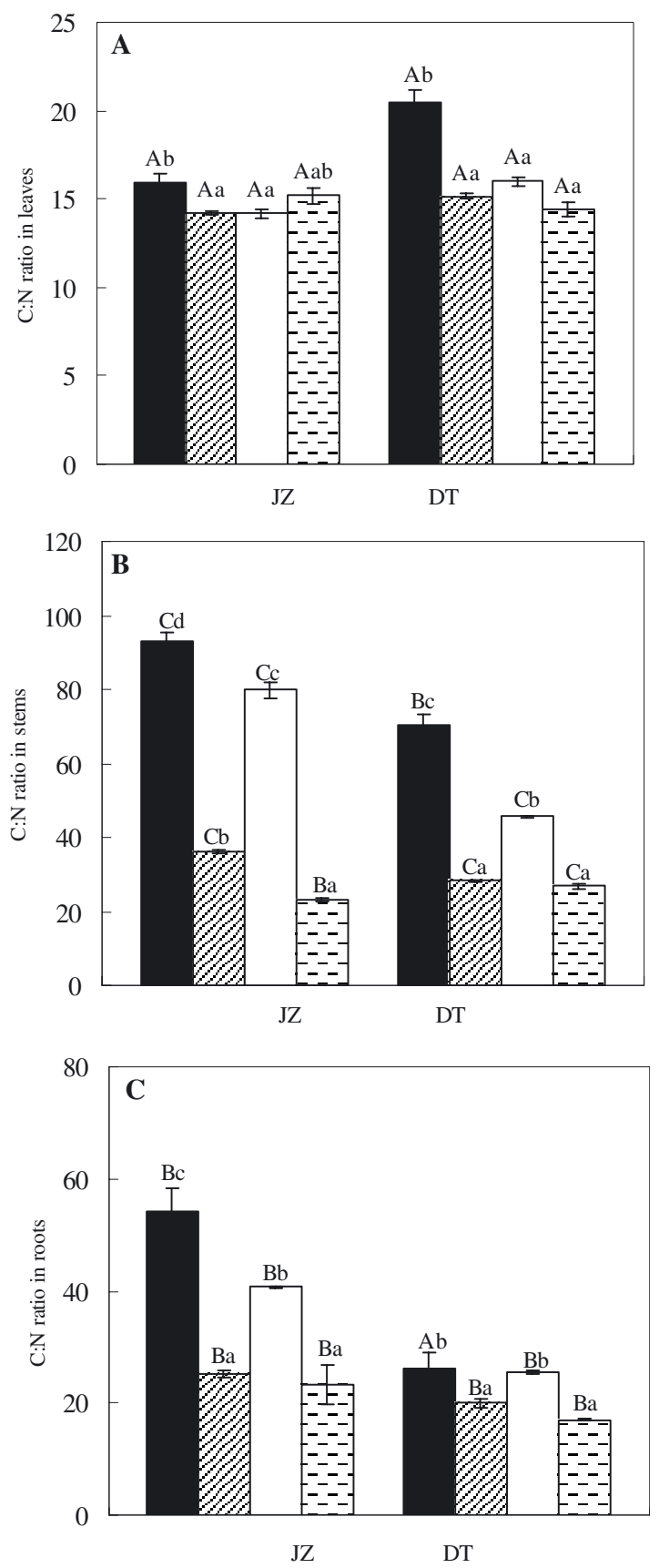

Figure 5. C:N ratio ( $\mathrm{g} \mathrm{g}^{-1} \mathrm{DW}$ ) in leaves (A), stems (B) and roots (C) in two contrasting $P$. cathayana populations exposed to different UV-B levels under well-watered or drought-stressed conditions. JZ, the population from the low altitude; DT, the population from the high altitude. Treatments: well-watered+no enhanced UVB application (black area), drought+no enhanced UV-B application (lined area), well-watered+enhanced UV-B application (white area), drought+enhanced UV-B application (stippled area). Values followed by the same small letters above the bars are not significantly different at the $P<0.05$ level according to Duncan multiple range test. Different capital letters above the bars refer to significant differences between the organs under the same population and treatment at $P<0.05$ level according to Duncan's multiple range test, respectively. Values are means $\pm \mathrm{SE}, n=5$.

\section{DISCUSSION}

\subsection{The growth and physiological responses as affected by drought}

Drought significantly decreased biomass accumulation in the two $P$. cathayana populations, similarly as previously reported for $P$. cathayana and other plants species (Anyia and Herzog, 2004; Li and Wang, 2003; Puértolas et al., 2008). Also for $R W C$, a significant decrease due to drought was observed. In general, a reduction in the leaf water content results in a decline in growth and stomatal conductance. In addition to decreases in biomass accumulation and $R W C$, some physiological traits were also found to be affected by drought. For example, drought significantly decreased gas exchange parameters, such as $A, g_{s}$ and $E$, as also reported in many previous studies (Duan et al., 2005; Zhang et al., 2004). It seems surprising that in spite of the tremendous effects on biomass accumulation, the corresponding drought effects on net photosynthesis were modest. Perhaps the kinetics of $A$ versus time, the incorporation of measurements from earlier stages of the experiment, would explain this matter. That is, the effects of drought on gas exchange were instantaneous and the effects on biomass accumulation were cumulative through the growing season. Also, the observed increases in the $\mathrm{N}$ content could have mitigated the effects of drought on photosynthesis (Susiluoto and Berninger, 2007). In our study, drought significantly increased $W U E_{\mathrm{i}}, W U E_{\mathrm{T}}$ and $\delta^{13} \mathrm{C}$, similarly as discovered by Bacelar et al. (2007) in olive cultivars and by Piper et al. (2007) in Nothofagus dombeyi.

Many previous studies have suggested that drought stress promotes the synthesis of ABA (Taylor et al., 2000) and regulates $\mathrm{pH}$-dependent compartmentation of ABA to the apoplast of stomatal guard cells (Hartung et al., 1998), with resulting changes in stomatal aperture, which may further result in an increase in WUE. In our study, a significant drought-induced increase in ABA was observed. It seems that the higher water use efficiency and better performance of the high altitude population was caused by the higher ABA concentration. In our study, the $\mathrm{N}$ content increased with drought in both populations. A comparable result has been reported by Sinclair et al. (2000), while Nilsson and Wiklund (1994) reported that drought does not affect the leaf $\mathrm{N}$ content in Picea abies $\mathrm{L}$. A possible explanation for the increase in $\mathrm{N}$ observed in this study is that the accumulation of leaf soluble protein under drought stress may represent a reserve of nitrogen to be used during the recovery after drought (Millard, 1988). A greater N content present in the high altitude population than in the low altitude population matches with the higher $A$ value detected in the high altitude population. This is due to the fact that the majority of leaf $\mathrm{N}$ is associated with the photosynthetic function of the leaf (Makino and Osmond, 1991). Although the annual mean rainfall is $67 \mathrm{~mm}$ greater on the high elevation site than on the low elevation site, the trees showed increasing acclimations to drought with increasing altitude, perhaps because the trees may suffer from drought stress induced by frozen, unavailable soil water or damaged foliage at high altitude. One possibility is also that colder soils reduce the water 
uptake of the root system and induce water stress (Magnani and Borghetti, 1995).

\subsection{The growth and physiological responses as affected by enhanced UV-B radiation}

Enhanced UV-B radiation has been shown to induce various responses in deciduous woody species from morphological alterations to multiple changes in phytochemistry (Sullivan et al., 2003). Thus, it is natural to observe a significant decrease in the biomass accumulation of $P$. cathayana seedlings induced by enhanced UV-B radiation. The $\mathrm{R} / \mathrm{S}$ ratio was found unaffected under enhanced UV-B radiation in the low altitude population, as also detected in previous studies (Schumaker et al., 1997). However, our results were in contrast with the studies by Bassman et al. (2003) that showed that under enhanced UV-B radiation $\left(21.8 \mathrm{~kJ} \mathrm{~m}^{-2} \mathrm{day}^{-1}\right)$ the shoot/root ratios of Pinus ponderosa Douglas ex C. Lawson, Pseudotsuga menziesii Franco and Quercus rubra L. generally increased. The variable responses in $R / S$ may explain the specific adaptation mechanisms present in different species under enhanced UV-B radiation.

The exposure of $P$. cathayana cuttings to increased UV-B radiation impairs the main processes of photosynthesis, including the stomatal diffusion of $\mathrm{CO}_{2}$ into the leaf and $\mathrm{CO}_{2}$ assimilation, as also proposed by Teramura and Sullivan (1994) for other terrestrial plants. However, carbohydrate accumulation in leaves during photosynthesis is a common phenomenon that can be enhanced by a low sink demand (Neales and Incoll, 1968). As UV-B radiation treated plants are known to have a tendency to have a lower sink capacity (Correia et al., 2000), the observed decreases in the $\mathrm{C}$ content of leaves induced by UV-B radiation indicate that the main response is mediated by a lower net photosynthetic rate. Similar results have been reported by Mackerness et al. (1997). In our study, compared with the low altitude population, the high altitude population exhibited a higher biomass accumulation, water-use efficiency as well as ABA accumulation, as affected by enhanced UV-B radiation, which indicates that the high altitude population is more responsive to enhanced UV-B radiation. Comparable patterns in biomass accumulation and water-use efficiency ín high and low altitude populations have been reported by Piper et al. (2007).

The leaves and stems of $P$. cathayana from the high altitude population showed a significant increase in the $\mathrm{N}$ content, as induced by enhanced UV-B radiation. This result is in contrast with the results reported by de la Rosa et al. (2001) in silver birch (Betula pendula Roth) seedlings, in which increasing UV-B radiation did not affect the $\mathrm{N}$ content. This discrepancy indicates that there are various responses to enhanced UV-B radiation among tree species. Compared with the leaves, the $\mathrm{N}$ content of stems and roots was significantly lower under enhanced UV-B radiation. We believe that this may be an allometric effect, since larger stems usually have a lower N content. Stewart et al. (1992) have reported that the fast-growing pioneer species assimilate nitrate primarily in the leaves, whereas climax species assimilate nitrate mainly in the roots. Poplars are among the fastest growing temperate tree species with a heterophyllous growth habit and they are considered to be pioneer tree species (Eckenwalder, 1996). Thus, it is expected that the $\mathrm{N}$ content is highest in the leaves of $P$. cathayana. On the other hand, the C:N ratio has been used to estimate the long-term nitrogen use efficiency (NUE) according to Livingston et al. (1999). Martin et al. (2002) have also suggested that the C:N ratio may be an important signal for the control of gene expression in plants. The observed decrease in the C:N ratio under drought and enhanced UV-B radiation indicate that the two stresses decrease the long-term NUE of poplar cuttings due to the reduction of the $\mathrm{C}$ content and the increase of the $\mathrm{N}$ content, and that they may also induce parallel changes in the metabolite levels following the $\mathrm{C}: \mathrm{N}$ ratio as an important signal for gene expression. In nature, the interactions of drought stress and UV-B radiation are very difficult to examine because of the effects of other environmental factors. Our study was carried out under controlled environments with a square-wave UV-B delivery system providing a high UV-B dosage $\left(12.4 \mathrm{~kJ} \mathrm{~m}^{-2} \mathrm{~d}^{-1}\right)$. The experimental set-up probably promoted the effects of UV-B, as the deleterious effects of UV-B are augmented by low PAR (reviewed in Bornman and Teramura, 1993). Thus, caution will be necessary when extrapolating the findings from the present study to the field. Nevertheless, our study suggests a potential mechanism for drought and UV-B effects on plant growth and physiology while keeping other growth conditions favourable.

\subsection{The growth and physiological responses as affected by the combination of drought and enhanced UV-B radiation}

The results obtained from the biomass accumulation and gas exchange measurements after one growing season of exposure to different UV-B radiation levels and watering regimes showed that the decreases induced by drought were most pronounced under the combination of UV-B radiation and drought. An additive effect of drought and UV-B radiation was observed in WUE and ABA. Moreover, the amount of UV-B absorbing compounds in the double-stress treatment was lower than that under single-stress conditions. This suggests that UVB blocked the drought-induced increase in the level of UV-B absorbing compounds or vice versa. Furthermore, PNUE (A/N ratio) was consistently lower for the drought-UV-B plants. Therefore, environmental conditions allowing plants acclimate in a way to fix more $\mathrm{CO}_{2}$ while using less $\mathrm{N}$ instead of fixing more $\mathrm{CO}_{2}$ at the expense of using more N. Our results are partly different from the report by Yang et al. (2005) in Hippophae rhamnoides $\mathrm{L}$., which indicated that the combination of drought and UV-B radiation may cause synergistically detrimental effects in a low altitude population but may alleviate the adverse impact brought about by drought in the high altitude population. According to Hofmann et al. (2003), dependency on the duration or severity of drought may help to explain divergent findings in the extent and direction of the UV-B $\times$ drought interactions among different studies. Whether our results obtained in experimental conditions can hold in 
the field may depend on the presence of concurrent environmental factors. In fact, the studied parameters related to UV-B sensitivity can be altered also in response to changing environmental conditions due to the elevational gradient in light, temperature, nutrient or water availability (Filella and Peñuelas, 1999). It is important to note that we can not determine whether the differences observed here were due to elevation alone, as our research, based on a comparison of two populations, was too restricted to provide conclusive answers to this question. Nonetheless, our research showed that the observed differences between the high and low altitude populations of $P$. cathayana may have resulted from stronger selection pressures present in the high altitude population. It is possible that the adaptation of the high altitude population has involved the evolution of morphological and physiological traits that facilitate a greater plasticity to environmental variability, allowing a better exploitation of resources in harsh conditions, compared to the low altitude population.

In conclusion, the results of the present study provide evidence for individual and interactive effects of two important environmental factors, drought and UV-B radiation, that affect the growth and development of poplars. Our results showed that UV-B radiation acts as an important signal allowing $P$. cathayana seedlings to respond to drought and that the combination of drought and UV-B radiation may cause synergistically detrimental effects on plant growth in both low and high altitude populations. The levels of UV-B radiation used in this study $\left(12.4 \mathrm{~kJ} \mathrm{~m}^{-2} \mathrm{~d}^{-1}\right)$ are similar to the amount of radiation experienced in the eastern Himalaya with a 25\% stratospheric ozone reduction during a clear day around summer solstice according to a mathematical model by Madronich et al. (1995) but lower than the amount expected to occur with a $30 \%$ depletion in the stratospheric ozone $\left(15.1 \mathrm{~kJ} \mathrm{~m}^{-2} \mathrm{~d}^{-1}\right)$ (Zhao et al., 2003). We conclude that $P$. cathayana seedlings will show symptoms of an UV-B stress if the intensity of UV-B radiation will increase in the future. On the other hand, this study also demonstrated that there are different adaptive responses between the contrasting $P$. cathayana populations, the high altitude population exhibiting higher tolerance to drought and UV-B radiation than does the low altitude population. Previous studies have suggested that plant growth strategies involve a trade-off between productivity, tolerance to stress, and ability to compete (Grime, 1977). Our results are in accordance with ecological models of the evolution of stress tolerance, which predict higher tolerance for the high altitude populations (Sullivan et al., 1992).

Acknowledgements: The research was supported by the Outstanding Young Scientist Program of the National Science Foundation of China (No. 30525036) and the Program of "Knowledge Innovation Engineering" of the Chinese Academy of Sciences (No. KSCX2YW-N-064).

\section{REFERENCES}

Alexieva V., Sergiev I., Mapelli S., and Karanov E., 2001. The effect of drought and ultraviolet radiation on growth and stress markers in pea and wheat. Plant Cell Environ. 24: 1337-1344.

Anyia A.O. and Herzog H. 2004. Water use efficiency, leaf area and leaf gas exchange of cowpeas under mid-season drought. Eur. J. Agron. 20: $327-339$.
Bacelar E.A., Moutinho-Pereira J.M., Goncalves B.C., Ferreira H.F., and Correia C.M., 2007. Changes in growth, gas exchange, xylem hydraulic properties and water use efficiency of three olive cultivars under contrasting water availability regimes. Environ. Exp. Bot. 60: 183-192.

Bassman J.H., Edwards G.E., and Robberecht R., 2003. Photosynthesis and growth in seedlings of five forest tree species with contrasting leaf anatomy subjected to supplemental UV-B radiation. For. Sci. 49: $176-187$.

Bornman J.F. and Teramura A.H., 1993. Effects of ultraviolet-B radiation on terrestrial plants. In Young A.R., Björn L.O., and Nultsch W. (Ed), environmental UV photobiology, Plenum Press, New York, pp. 427-471.

Bradford M.M., 1976. A rapid and sensitive method for the quantification of microgram quantities of protein utilizing the principle of proteindye binding. Ann. Biochem. 72: 248-254.

Caldwell M.M., 1971. Solar ultraviolet radiation and growth and development of higher plants. Photophysiology, Vol. 6. In: Giese A.C. (Ed.), Academic press, New York, pp. 131-137.

Correia C.M., Coutinho J.F., Björn L.O., and Torres-Pereira J.M.G., 2000. Ultraviolet-B radiation and nitrogen effects on growth and yield of maize under Mediterranean field conditions. Eur. J. Agron. 12: $117-125$.

Craig H., 1957. Isotopic standards for carbon and oxygen and correction factors for mass-spectrometric analysis of carbon dioxide. Geochim. Cosmochim. Acta 12: 133-149.

Dai Q., Furness N.H., and Upadhyaya M.K., 2004. UV-absorbing compounds and susceptibility of weedy species to UV-B radiation. Weed Biol. Manage. 4: 95-102.

de la Rosa T.M., Julkunen-Tiitto R., Lehto T., and Aphalo P.J., 2001. Secondary metabolites and nutrient concentrations in silver birch seedlings under five levels of daily UV-B exposure and two relative nutrient addition rates. New Phytol. 150: 121-131.

Duan B., Lu Y., Yin C., Junttila O., and Li C., 2005. Physiological responses to drought and shade in two contrasting Picea asperata populations. Physiol. Plant. 124: 476-484.

Eckenwalder J.E., 1996. Systematics and evolution of Populus. Biology of Populus and its implications for management and conservation. In: Stettler R.F., Bradshaw H.D., Heilman J.P.E., and Hinckley T.M. (Eds), NRC Research Press, Ottawa, pp. 7-32.

Farquhar G.D., Ehleringer J.R., and Hubick K.T., 1989. Carbon isotope discrimination and photosynthesis. Annu. Rev. Plant Physiol. Plant Mol. Biol. 40: 503-537.

Filella I. and Peñuelas J., 1999. Altitudinal differences in UV absorbance, UV reflectance and related morphological traits of Quercus ilex and Rhododendron ferrugineum in the Mediterranean region. Plant Ecol. 145: $157-165$.

Grime J.P., 1977. Evidence for the existence of three primary strategies in plants and its relevance to ecological and evolutionary theory. Am. Nat. 111: 1169-1194.

Grossman A. and Takahashi H., 2001. Macronutrient utilization by photosynthetic eukaryotes and the fabric of interactions. Annu. Rev. Plant Physiol. Plant Mol. Biol. 52: 163-210.

Hartung W., Wilkinson S., and Davies W., 1998. Factors that regulate abscisic acid concentrations at the primary site of action at the guard cell. J. Exp. Bot. 49: 361-367.

Hofmann R.W., Campbell B., and Fountain D.F., 2003. Sensitivity of white clover to UV-B radiation depends on water availability, plant productivity and duration of stress. Global Change Biol. 9: 473-477.

Hubner C. and Ziegler H., 1998. UV-B effects on physiological parameters of three species of Rumex with natural distribution at different altitudes. J. Plant Physiol. 152: 336-344. 
Li C., 2000. Population differences in water use efficiency of Eucalyptus microtheca seedlings under different watering regimes. Physiol. Plant. 108: 134-139.

Li C., Berninger F., Koskela J., and Sonninen E., 2000. Drought responses of Eucalyptus microtheca provenances depend on seasonality of rainfall in their place of origin. Aust. J. Plant Physiol. 27: 231-238.

Li C., Puhakainen T., Welling A., Viherä-Aarnio A., Ernstsen A., Junttila O., Heino P., and Palva E.T., 2002. Cold acclimation in silver birch (Betula pendula) development of freezing tolerance in different tissues and climatic ecotypes. Physiol. Plant. 116: 478-488.

Li C. and Wang K., 2003. Differences in drought responses of three contrasting Eucalyptus microtheca F. Muell. populations. For. Ecol. Manage. 179: 377-385.

Livingston N.J., Guy R.D., and Ethier G.J., 1999. The effects of nitrogen stress on the stable carbon isotope composition, productivity and water use efficiency of white spruce (Picea glauca (Moench) Voss) seedlings. Plant Cell Environ. 22: 281-289.

Mackerness S.A.H., Surplus S.L., Jordan B.R., and Thomas B., 1997. Ultraviolet-B effects on transcript levels for photosynthetic genes are not mediated through carbohydrate metabolism. Plant Cell Environ. 20: 1431-1437.

Madronich S., Mckenzie R.L., Caldwell M.M., and Björn L.O., 1995. Changes in ultraviolet radiation reaching the earth's surface. Ambio. 24: $143-153$.

Magnani F. and Borghetti M., 1995. Interpretation of seasonal changes of xylem embolism and plant hydraulic resistance in Fagus sylvatica. Plant Cell Environ. 18: 689-696.

Makino A. and Osmond B., 1991. Effects of nitrogen nutrition on nitrogen partitioning between chloroplasts and mitochondria in pea and wheat. Plant Physiol. 96: 355-362.

Martin T., Oswald O., and Graham I.A., 2002. Arabidopsis seedling growth, storage lipid mobilization and photosynthetic gene expression are regulated by carbon: nitrogen availability. Plant Physiol. 128: $472-481$.

Millard P., 1988. The accumulation and storage of nitrogen by herbaceous plants. Plant Cell Environ. 11: 1-8.

Neales T.F. and Incoll L.D., 1968. The control of leaf photosynthesis rate by the level of assimilate concentration in the leaf: a review of the hypothesis. Bot. Rev. 34: 107-125.

Nelson D.W. and Sommers L.E., 1982. Total carbon, organic carbon and organic matter. Methods of soil analysis, Part 2. In: Page A.L, Miller R.H., and Keeney D.R. (Eds), American society of agronomy and soil science, Madison, WI, pp. 539-579.

Nilsson L.O. and Wiklund K., 1994. Nitrogen uptake in a Norway spruce stand following ammonium sulphate application, fertilization, irrigation, drought and nitrogen-free-fertilization. Plant Soil 164: 221-228.

Nogues S. and Baker N.R., 2000. Effects of drought on photosynthesis in Mediterranean plants grown under enhanced UV-B radiation. J. Exp. Bot. 51: 1309-1317.

Petropoulou Y., Kyparissis A., Nikolopoulos D., and Manetas Y., 1995. Enhanced UV-B radiation alleviates the adverse effects of summer drought in two Mediterranean pines under field conditions. Physiol. Plant. 94: 37-44.

Piper F.I., Corcuera L.J., Alberdi M., and Lusk C., 2007. Differential photosynthetic and survival responses to soil drought in two evergreen nothofagus species. Ann. For. Sci. 64: 447-452.

Poulson M.E., Donahue R.A., Konvalinka J., and Boeger M.R.T., 2002. Enhanced tolerance of photosynthesis to high-light and drought stress in Pseudotsuga menziesii seedlings grown in ultraviolet-B radiation. Tree Physiol. 22: 829-838.
Puértolas J., Pardos M., Jiménez M.D., Aranda I., and Pardos J.A., 2008. Interactive responses of Quercus suber L. seedlings to light and mild water stress: effects on morphology and gas exchange traits. Ann. For. Sci. 65: 611-621.

Rau W. and Hofmann H., 1996. Sensitivity to UV-B of plants growing in different altitudes in the Alps. J. Plant Physiol. 148: 21-25.

Ren J., Dai W., Xuan Z., Yao Y., Korpelainen H., and Li C., 2007. The effect of drought and enhanced UV-B radiation on the growth and physiological traits of two contrasting poplar species. For. Ecol. Manage. 239: $112-119$.

Schumaker A.M., Bassman J.H., Robberecht R., and Radamaker G.K., 1997. Growth, leaf anatomy and physiology of Populus clones in response to solar ultraviolet-B radiation. Tree Physiol. 17: 617-626.

Sinclair T.R., Pinter P.J., Kimball B.A., Adamsen F.J., LaMorte R.L., Wall G.W., Hunsaker D.J., Adam N., Brooks T.J., Garcia R.L., Thompson T., Leavitt S., and Matthias A., 2000. Leaf nitrogen concentration of wheat subjected to elevated $\left[\mathrm{CO}_{2}\right]$ and either water or $\mathrm{N}$ deficits. Agr. Ecosyst. Environ. 79: 53-60.

Sinclair T.R., Tanner C.B., and Bennett J.M., 1984. Water-use efficiency in crop production. BioScience 34: 36-40.

Stewart G.R., Joly C.A., and Smirnoff N., 1992. Partitioning of inorganic nitrogen assimilation between the roots and shoots of cerrado and forest trees of contrasting plant communities of South East Brasil. Oecologia 91: 511-517.

Sullivan J.H. and Teramura A.H., 1989. The effects of ultraviolet-B radiation on loblolly pine. I. Growth, photosynthesis and pigment production in greenhouse-grown seedlings. Physiol. Plant. 72: 202-207.

Sullivan J.H., Gitz D.C., Peek M.S., and McElrone A.J., 2003. Responses of three eastern species to supplemental UV-B radiation: leaf chemistry and gas exchange. Agr. For. Meteorol. 120: 219-228.

Sullivan J.H., Teramura A.H., and Ziska L.H., 1992. Variation in UV-B sensitivity in plants from a 3000-m elevational gradient in Hawaii. Am. J. Bot. 79: 737-743.

Susiluoto S. and Berninger F., 2007. Interactions between morphological and physiological drought responses in Eucalyptus microtheca. Silva Fenn. 41: 221-233.

Taylor I.B., Burbidge A., and Thompson A.J., 2000. Control of abscisic acid synthesis. J. Exp. Bot. 51: 1563-1574.

Teramura A.H. and Sullivan J.H., 1994. Effects of UV-B radiation on photosynthesis and growth of terrestrial plants. Photosynth. Res. 39: 463-473.

Turtola S., Rousi M., Pusenius J., Yamaji K., Heiska S., Tirkkonen V., Meier B., and Julkunen-Tiitto R., 2006. Genotypic variation in drought response of willows grown under ambient and enhanced UVB radiation. Environ. Exp. Bot. 56: 80-86.

Weih M., Johanson U., and Gwynn-Jones D., 1998. Growth and nitrogen utilization in seedlings of mountain birch (Betula pubescens ssp. tortuosa) as affected by ultraviolet radiation (UV-A and UV-B) under laboratory and outdoor conditions. Trees 12: 201-207.

Yang Y., Yao Y., Xu G., and Li C., 2005. Growth and physiological responses to drought and elevated ultraviolet-B in two contrasting populations of Hippophae rhamnoides. Physiol. Plant. 124: 431-440.

Zhang X., Zang R., and Li C., 2004. Population differences in physiological and morphological adaptations of Populus davidiana seedlings in response to progressive drought stress. Plant Sci. 166: 791-797.

Zhao D., Reddy K.R., Kakani V.G., Read J.J., and Sullivan J.H., 2003. Growth and physiological responses of cotton (Gossypium hirsutum L.) to elevated carbon dioxide and ultraviolet-B radiation under controlled environmental conditions. Plant Cell Environ. 26: 771-782. 